\title{
Levels of Code Switching on EFL Student's Daily Language; Study of Language Production
}

\author{
Zainuddin \\ English and Language Literature Department, Faculty of Languages and Arts, Universitas Negeri Medan, Indonesia. \\ E-mail: zainuddin.gayo52@yahoo.com
}

Doi:10.7575/aiac.alls.v.7n.3p.278

URL: http://dx.doi.org/10.7575/aiac.alls.v.7n.3p.278
Received: 24/02/2016

Accepted: 14/04/2016

\begin{abstract}
This study is aimed at describing the levels of code switching on EFL students' daily conversation. The topic is chosen due to the facts that code switching phenomenon are commonly found in daily speech of Indonesian community such as in teenager talks, television serial dialogues and mass media. Therefore, qualitative data were collected by using diary notes and semi structure interview techniques. As the results, there were 15 examples of the code switching collected from the students' daily conversations, and there were 4 reasons why the students tend to switch codes. In conclusion, by using the general linguistics form, the students produced three levels of linguistics structure in code switching namely word level, phrase level and sentence (clause) level.
\end{abstract}

Keyword: Code Switching, Language Production and EFL Students

\section{Introduction}

\subsection{Background of the Study}

Nowadays, bilingual or multilingual cannot be avoided in daily language especially in youth daily language. It is called code switching. Code switching (CS) has become an interesting phenomenon to be studied particularly in the study of second language learning because it is one of the major aspects of bilingual developmental process. Generally, code switching can occur because of two reasons: first, the speaker's deficiency in the target language. Second, it is because of some multiple communicative purposes (Gysels cited in Duran, 1994).

Furthermore, code switching is seen as having certain function in the communication done by bilinguals or multilingual. Duran (1994), for example, states that code switching is firmly connected to bilingual. Other scholars say that code switching is also a psycholinguistic development result in a bilingual's conversation. Among them, Heredia and Brown (http://www.tamiu.edu) said that people who know more than one language naturally produce code switching.

Crystal (1987) asserted that code switching occurs when two persons alternate two languages in their conversations. It means that a person who knows more than one language makes a conversation with another person who knows more than one language too but those languages are same languages. This includes those who randomly use a second language in daily language, or those who have considerable skill in a foreign language. Therefore, This code switching commonly occurs among bilinguals, who switch words, phrases or/and sentences from other languages.

Berthold, Mangubhai and Bartorowicz (1997) found that code switching appears when speakers change from one language to another language in speech or conversations. An example of code switching from Indonesian language to English language "kamu handsome bangat sih" meaning "you are really handsome". The speakers switch the word "handsome" to replace Indonesian word "tampan" in the conversation.

Furthermore, Cook (1991) describes three linguistic level of code switching: word, phrase, and sentence (clause) levels. This level of the language would be used to identify the language level produced by the EFL students in Universitas Negeri Medan. Beside that, there are a number of possible reasons why switching from one language to another occurs. The first, a speaker may not be able to express him/herself in one language so switching to the other language to compensate for the deficiency. As a result, the speaker may be triggered into speaking in the other language for a while. The second, switching commonly occurs when an individual wishes to express solidarity with a particular social group (Crystal 1987).

English is a foreign language for the students in English Language and Literature Department Universitas Negeri Medan Indonesia. They use English for international communication and for Learning purpose. Since English is the language that they have to master, they have practiced English in their daily conversation. In natural conversation, they tend to use Indonesian language but they commonly switch English in the conversation. This is a common thing for the person who knows Indonesian language and English. This is something unique to be known in what extend they switch English in their conversation and the reasons in using code switching in the conversation. 
EFL students in Universitas Negeri Medan tended to switch codes in their daily conversation particularly switch English in their Indonesian language conversations. This code switching is really common among the students in UNIMED. Even though actually, this phenomenon is good for the students to improve their English but the exact reasons and the level of code switching are crucially needed to be known. Therefore, this research would focus on finding the level of the code switching and the reasons why the students tend to switch codes.

\subsection{Research Questions}

According to background of study and research problem, the research questions are formulated as follows:

1) What are the levels of code switching on EFL learners daily conversation in English Language and Literature Department Universitas Negeri Medan Indonesia?

2) What are the reasons of the learners in switching codes on their daily conversation?

\section{Literature Review}

Basically, code switching is a particular feature of bilinguals, which is related to situation where bilingual persons alternate between languages or within utterance (Greer, 2007). Moreover, Codes are usually in the varieties of language, which is used by members of a language community. For monolinguals, codes are the varieties of a language or the same language. But for bilingual or multilingual, the codes might include the varieties of two languages. Language has some classes of variety and they are different in each language such as dialect, speech level, and style. But for this research, the writer tends to be more concerned on linguistics level in the code switching.

Code switching (CS) is commonly used as an alterative language in conversational event. The term was first employed to refer to the coexistence of more than one structural system in the speech of one individual. Jakobson, Fant, and Halle (1952) who use "code" in the abstract information theoretical sense. In later writings, "code" has come a synonym of "language" or "speech variety". Recent research on CS falls within two distinct traditions: the syntactic, providing insights into the linguistic principles that underline the form that CS takes; and the pragmatic that relates linguistic form to function in everyday discourse. To eliminate the problem, the paper focuses on the linguistic level: word, phrase, and sentence (clause) levels and reasons of code switching habits.

Code switching normally occurs in informal speech or colloquial speech, which is the type of speech used in everyday, informal situations when the speaker is not paying particular attention to pronunciation, choice of words or sentence structure (Richard, 1985). Educated native speakers or language naturally use colloquial speech in formal situation with friends, fellow workers, and members of the family. Formal speech is a type of speech when the speaker is very careful about pronunciation and choice of words and sentence structure (Richard, 1985). This type of speech may be used, for example, at official functions, and in debates and ceremonies.

Specifically, there are three types of the code switching habits. The first is inter-sentential code switching, which occurs between utterances said by the same speakers. The second is intra-sentential which takes place within a sentence. The third is supra-sentential or unitary-code switching, which occurs when speaker switches a single item of the utterance (Milroy \& Myusken, 1995). Furthermore, Becker (1997) separates the factors that make bilingual speakers switch codes in to three types: structural linguistics factors, internal psycholinguistics factors, and external social factors.

Specifically, Zentella (as cited in Becker, 1997) elaborates that structural linguistics factors are attached in the language structure and in individual language knowledge. It means that bilingual speakers have the ability to keep the grammatical coherence of the both languages at the same time. Then, the internal psycholinguistics factors are separated in to two kinds: 1) unconscious factors, which contain a brief inclination, exposure frequency, and cultural untranslatability; and 2) conscious factors, which consist of an intention for emphasis, mode, controlling address, personalization, objectification. And last is an external and social nature such as participants, topic, setting and conditions.

Purposely, this research focuses on the second type of code switching habits. It means that the study is willing to find out the linguistics levels (word, phrase, and sentence), which take place in the sentence within the conversation. Then, determine the students' reasons in switching codes whether it belongs to the first, the second, or the third factors mentioned by Becker (1997).

\section{Methodology}

\subsection{Subjects of the Study}

The subjects of this study were the EFL students in English Language and Literature Department, Universitas Negeri Medan Indonesia. The number of the students in this department was 840 students. The range of the ages is 17 to 23 years old.

\subsection{Data Collection and Analysis Techniques}

The data collected were qualitative data. The techniques used of collecting data were diary notes and semi-structured interview. The data code-switching data were collected from the daily conversation of the students. And the semistructured interview was used to get the reason why the students were using code switching on their conversations. Levels of the linguistics structure in their sentence were analyzed by using the theory of words form (word, phrase, and 
clause/sentence) in English Language (Meyer, 2009). Thus, the code switching in the conversation would be categorized in to three levels, which are words, phrases and clauses/sentences. Then, it would be calculated which level the students used most in their conversation.

\section{Data Analysis}

4.1 Code Switching Expressions and the Levels of Linguistic Structure

Here are 15 expressions chosen as the data collection. Here are the examples of expression considered code switching from students in English Language and Literature Department, Universitas Negeri Medan.

1. “Hang out yok!”,

2. “Kita lagi on line lah",

3. “Maaf ya komputer aku lagi error”,

4. “Wah, kayaknya dia lagi offline”,

5. “Boleh tahu nggak e-mail kamu?”,

6. "Love you bangat",

7. “Miss you bangat.",

8. "Kamu bisa call aku anytime",

9. Aku belom save tuh nomor kamu yang baru,

10. “Kayaknya dia jealous deh, sama kau.”,

11. "Hey, Ini Randy kenalan yok! I think you are cute bangat",

12. “I juga bilang kalau you emang ada talent”,

13. "Aku bingung dan I don't know what I have to do",

14. “You tahu kan kalo I tidak suka sama you”,

15. "Coba isi saja application form itu ya!",

4.1.1 Analyzing Code Switching (CS) Expressions and Linguistic Level

a. Code Switching in Word Level

“You tahu kan kalo I tidak suka sama you”.

Table 1. Code Switching in Word Level

\begin{tabular}{ccccc}
\hline CS & $\begin{array}{c}\text { Indonesian } \\
\text { expression }\end{array}$ & CS & $\begin{array}{c}\text { Indonesian } \\
\text { expression }\end{array}$ & CS \\
\hline I & juga bilang kalau & you & ada & talent \\
\hline
\end{tabular}

The linguistics level of the above example lies on word level. The speaker just change the Indonesian word of saya into I and kamu into you. The linguistic analysis is by changing the subject and object. Then, they change the word bakal into talent. Thus, I, you, and talent belong to words in English Linguistics (Meyer, 2009). "I" is a pronoun and the function is as a subject, while "you" is a pronoun too but can be as a subject or object in a sentence. Then, "talent" is a noun.

b. Code Switching in Phrase Level

Coba isi saja application form itu!",

Table 2. Code Switching in Phrase Level

\begin{tabular}{lcccc}
\hline $\begin{array}{c}\text { Indonesian } \\
\text { expression }\end{array}$ & $\begin{array}{c}\text { Indonesian } \\
\text { expression }\end{array}$ & $\begin{array}{c}\text { Indonesian } \\
\text { expression }\end{array}$ & $\begin{array}{c}\text { English } \\
\text { Expression }\end{array}$ & $\begin{array}{c}\text { Indonesian } \\
\text { Expression }\end{array}$ \\
\hline coba & isi & saja & $\begin{array}{c}\text { Application } \\
\text { form }\end{array}$ & itu \\
\hline
\end{tabular}

The Code Switching comes in when the phrase "Formulir pendaftaran" becomes "Application Form" which contains two words: Application and Form. According to Meyer (2009) this expression is phrase level in English Linguistics.

\section{c. Code Switching in Sentence Level}

"Aku tuh bingung dan I really don't know what I have to do"

$$
S \text { adv V Obj (noun clause as object) }
$$


Table 3. Code Switching in Sentence Level

\begin{tabular}{cl}
\hline Indonesian expression & CS \\
\hline Aku tuh bingung & I really don't know what I have to do \\
\hline
\end{tabular}

The linguistic level of the above expression is on sentence level. The code switching of the Indonesia expression "saya ngak tahu lagi apa yang harus kulakukan" rendered into I really don't know what I have to do. The linguistic level categorized as sentence is that the expression occurs in sentence type. The part of speech of the expression is $I$ (subject), really (adverb), don't know (verb), and what I have to do (noun clause as object) (Meyer, 2009).

In accordance with the levels of the code switching produced by the EFL learners in English Language and Literature Department Universitas Negeri Medan Indonesia, it can declared that the students have already reached the three level of the English linguistics which are words, phrases, and clause (sentence) levels.

\subsection{Reasons for Switching Codes}

Data from interview to 15 students in English and literature Department State University of Medan reveals that most of code switching occurs in certain situation. These students said in the interview that they use English because they did not know the Indonesian equivalence such as e-mail, online, offlline and etc. Some thought that the use of Indoglish makes the conversation more prestigious like application form. And others said that they switched code in order to adapt with the situation. Also, there is the influence of the specific intentions or purposes of the bilingual or multilingual to use the expressions in their communication performance. It means that the reasons of switching codes in students daily conversation English Language and Literature Department Universitas Negeri Medan fall more in to the second and the third factors, which are internal psycholinguistics factors and external social factors respectively.

\section{Conclusion}

Throughout the research, the phenomenon of the code switching is presented to their usages in bilingual and multilingual community. It can be concluded that, the code switching occurred in the word, phrase and sentence levels. The reasons of using those expressions are mostly influenced by situation and not knowing the Indonesian language preference. Therefore, from this research there are two contrasted things will be happened. First, the English of the students is naturally appeared. Thus, the aim of implicitly acquiring English has been appeared. Second, the defense of national language (Indonesian language) has been defaced.

\subsection{Limitation of the Study and Recommendation}

Actually, this study is a simple study and of course there is limitation on this study. This study actually is only focusing on the levels of the code switching and reasons why the learners switch code. Moreover, the participants were only the students from English Language and Literature Department Universitas Negeri Medan. Then, the analysis of the code switching is only about the linguistics level of the code. And the researcher only used the diary notes and semistructured interview only collecting the data.

Therefore, there are some of the recommendations to the future researchers. First, the next researchers are expected to do the code switching study on more particular and specific analysis such as semantic, syntactic, morphology, and pragmatic aspects in code switching. Second, the next researchers can do the research on the advantages and disadvantages of the code switching in social life or classroom usage. Third, the future researches are expected to do the research in bigger number of the participants, use the variety techniques of collecting data and analysis.

\section{References}

Becker, K. (1997). Spanish/English bilingual code switching: A syncretic model. Bilingual Review, 22(1), 1-36.

Berthold, M., Mangubhai, F., and Batonwicz, K. (1997). Bilingual \& Multilingualism: Study Book. Distance Education Centre. Toowoomba: University of Southern Queensland.

Cook, V. (1991). Second Language Learning and Language Teaching. Melbourne: Hodder Headline group.

Crystal, D. (1987). The Cambridge Encyclopedia of language. Cambridge: Cambridge University Press.

Duran, L. (1994). Toward a Better Understanding of Code Switching and Interlanguage in Bilinguality: Implication for Bilingual Instruction. In http://www.ncela.gwu.edu. Retrieved: Oct $4^{\text {th }}, 2007$.

Greer, T. (2007). Accomplishing identity in bilingual interaction: Code switching practices among a group of multiethnic Japanese teenagers. Unpublished Ph.D. University of Southern Queensland Australia.

Meyer, C. F. (2009). Introducing English Linguistics. New York: Cambridge University Press.

Milroy, L., \& Muysken, P. (1995). One speaker, two languages cross-disciplinary perspectives on code switching. New York: Cambridge University Press.

Richard, K. (1985). Principle of Particle Construction. In Jacqueline Gueron, Hans-Georg Obenauer, and Jean-Yues Pollock, eds., Grammatical Representation. Dordrecht, The Netherlands: Foris Publications. 